\title{
DESIGN AND BUILD UP THE STIRRER VISCOMETER
}

\author{
Lamria Sri Manurung ${ }^{* 1}$, Hendar Sudrajad ${ }^{2)}$ \\ ${ }^{1,2)}$ Physics Education, University of Riau \\ e-mail: hendarsudrajad61@gmail.com \\ lamryamanurung@gmail.com
}

\begin{abstract}
Fluids are substances that can flow. One of the flow substances is liquid. Every liquid has a characteristic that distinguishes a liquid from another liquid. One characteristic of a liquid is viscosity (thickness). The measuring instrument used to determine the viscosity of a liquid is a viscometer. Due to the importance of the amount of viscosity, so it is necessary to know the measurement easily, cheaply, and thoroughly. One method is to use a stirrer viscometer as a liquid viscous measurement devices. The purpose of this research was to determine the construction and test the designed stirrer viscometer. The research method used is the experimental method. The procedure of this research includes designing, assembling, and testing a stirring viscometer. The results of experiments that have been carried out show that the stirrer viscometer devices can to used to measure the viscosity of liquids with time and temperature indicators. This tool effectively proves that the temperature affects the viscosity of a liquid where the higher the temperature of the liquid, the lower the value of the viscosity of the liquid, and conversely the lower the temperature of the liquid, the higher the viscosity value of the liquid.
\end{abstract}

Keywords: fluids, temperature, viscocity

\section{RANCANG DAN BANGUN VISKOMETER STIRER}

\author{
Lamria Sri Manurung ${ }^{1)}$, Hendar Sudrajad ${ }^{2)}$ \\ ${ }^{1,2)}$ Pendidikan Fisika, Universitas Riau
}

\begin{abstract}
Abstrak
Fluida adalah zat yang dapat mengalir. Salah satu zat alir adalah zat cair. Setiap zat cair mempunyai karakteristik yang khas yang membedakan suatu zat cair dengan zat cair yang lain. Salah satu karakteristik dari zat cair adalah viskositas (kekentalan). Alat ukur yang digunakan untuk menentukan kekentalan (viskositas) suatu zat cair adalah viskometer. Berhubung pentingnya besaran viskositas, maka perlu diketahui metode pengukurannya secara mudah, murah dan teliti. Salah satu metode itu adalah menggunakan viskometer stirer sebagai alat ukur kekentalan zat cair. Tujuan penelitian ini adalah untuk mengetahui kontruksi dan melakukan pengujian terhadap viskometer stirer yang dirancang. Metode penelitian yang digunakan adalah metode eksperimen. Prosedur penelitian ini meliputi perancangan, perakitan, dan pengujian alat viskometer stirer. Hasil eksperimen yang telah dilakukan menunjukkan bahwa alat viskometer stirer yang dibuat dapat digunakan untuk melakukan pengukuran viskositas zat cair dengan indikator waktu dan suhu. Alat ini dapat membuktikan bahwa suhu mempengaruhi viskositas suatu zat cair dimana semakin tinggi suhu zat cair, maka semakin rendah nilai viskositas zat cair, dan sebaliknya semakin semakin rendah suhu zat cair, maka semakin tinggi nilai viskositas zat cair tersebut.
\end{abstract}

Kata kunci: fluida, suhu, viskositas 


\section{Pendahuluan}

Fluida merupakan suatu jenis zat yang dapat mengalir. Salah satu jenis fluida adalah zat cair. Zat cair menyesuaikan diri dengan bentuk wadah apapun dimana fluida tersebut ditempatkan. Fluida bersifat demikian karena tidak dapat menahan gaya yang bersinggungan dengan permukaannya. Setiap zat cair mempunyai karakteristik yang khas, yang membedakan suatu zat cair dengan zat cair yang lain. Salah satu karakteristik yang membedakan sifat zat cair adalah viskositas (kekentalan). Setiap zat cair ini memiliki nilai kekentalan yang berbeda-beda, misalnya, oli bersifat lebih kental daripada minyak kelapa.

Viskositas adalah ukuran kekentalan fluida yang menyatakan besar kecilnya gesekan di dalam fluida. Semakin besar viskositas fluida, maka semakin sulit suatu benda bergerak di dalam fluida tersebut. Pada zat cair, viskositas dihasilkan oleh gaya kohesi antara molekul zat cair sedangkan dalam gas, viskositas timbul sebagai akibat tumbukan antara molekul gas (Maulida, 2010). Zat cair dengan viskositas tinggi lebih sulit mengalir dibandingkan zat cair dengan viskositas rendah sehingga semakin lama waktu fluida mengalir, semakin tinggi nilai viskositasnya (Samdara \& Muqorobin, 2008).

Suatu fluida ideal (fluida tidak kental) tidak memiliki viskositas (kekentalan) yang menghambat lapisan-lapisan fluida ketika lapisan-lapisan tersebut menggeser satu di atas lainnya. Untuk fluida yang sangat kental seperti madu, diperlukan gaya yang lebih besar, sedangkan untuk fluida yang kurang kental (viskositasnya kecil), seperti air, diperlukan gaya yang lebih kecil. Tingkat kekentalan suatu fluida juga bergantung pada temperatur. Semakin tinggi temperatur zat cair, semakin rendah kekentalan zat cair tersebut. Ketika minyak goring dipanaskan, minyak yang awalnya kental menjadi lebih cair. Sebaliknya, semakin rendah suhu, semakin kental zat cair tersebut.

Umumnya, suatu fluida akan mengalami pengurangan viskositas jika temperatur dinaikkan. Hal ini berkaitan dengan struktur molekul dalam fluida tersebut. Ketika temperatur naik maka partikel-partikel penyusun fluida akan menjadi semakin besar sehingga pergerakannya makin cepat sehingga menyebabkan cairan lebih mudah mengalir atau disebut juga viskositas fluida lebih rendah. Peningkatan temperature menyebabkan berkurangnya gaya kohesi antar partikel dan ini menyebabkan berkurangnya viskositas fluida (Olson, 1993).

Alat ukur yang digunakan untuk menentukan kekentalan (viskositas) suatu zat cair adalah viskometer. Alat ukur kekentalan ini dapat mengukur tingkat kekentalan suatu zat cair dengan akurat dan spesifik sesuai dengan standar yang telah ditentukan. Dalam pembuatannya. Viskometer ditujukan untuk memperoleh waktu sehingga dapat dihitung nilai viskositas suatu fluida (Ridwan, et al., 2012). Viskometer terdiri dari berbagai jenis. Model viskositas yang umum digunakan diantaranya yaitu bola jatuh, bola bergulir, pipa kapiler, rotasi silinder kosentris, dan rotasi kerucut plat (Shanti, et al., 2014).

Saat ini viscometer memiliki peranan dan fungsi penting. Kegiatan praktikum di sekolah membutuhkan viskometer untuk mempelajari sifat kekentalan suatu fluida. Perusahaan yang bergerak dan berhubungan dengan fluida membutuhkan alat ini untuk menguji tingkat kekentalan fluida (Ridwan, et al., 2012). Berhubung pentingnya besaran viskositas maka perlu diketahui metode pengukurannya secara mudah, murah, dan teliti. Salah satu metode yang dapat digunakan adalah viskometer stirer. Viskometer stirer tergolong jenis viskometer yang menggunakan metode sistem rotasi. Viskometer Stirer digunakan untuk mendapatkan nilai viskositas dengan cara kerja berdasarkan selang waktu yang dibutuhkan oleh beban untuk jatuh ke tanah akibat hambatan yang diberikan fluida kepada stirer.

Alat praktikum yang baik haruslah memenuhi kriteria valid, praktis, dan efektif. Validasi poduk dapat dilakukan dengan cara meminta beberapa tenaga ahli atau para pakar untuk menilai dan memberi masukan mengenai suatu produk yang dikembangkan. Penilaian tersebut berguna untuk mengetahui kelemahan dan kekuatan produk Sugiyono (2012). Validasi dapat dilakukan dengan cara memberikan beberapa instrument penilaian kepada tenaga ahli untuk menilai kelayakan suatu produk atau dapat juga dilakukan dengan memperagakan dan mendemonstrsikan kerja alat lalu meminta tanggapan para ahli. Namun 
demikian dalam kajian ini baru sampai pada tahap perancangan, pembuatan, dan pengujian keberfungsian alat viskometer stirer.

Berdasarkan uraian yang telah dijelaskan, maka diperlukan suatu alat pengukur kekentalan suatu zat cair yang memiliki tingkat ketelitian yang akurat. Rancang bangun sebuah alat viskometer stirer perlu dipaparkan untuk membuat suatu alat yang baik dan efektif. Maka dari itu, dengan dirancang dan dibangunnya viskometer stirer ini, maka diharapkan akan mempermudah untuk menentukan nilai viskositas dari suatu zat cair. Penelitian ini memiliki dua tujuan, yaitu untuk mengetahui konstruksi viskometer dan untuk menentukan validitas alat viskometer yang dirancang.

\section{Bahan dan Metode}

Penelitian dilakukan di laboraturium Pendidikan Fisika Fakultas Keguruan dan Ilmu Pendidikan Universitas Riau, pada bulan Februari 2018 sampai bulan Mei 2018. Alat yang digunakan adalah akrilik, wadah, baut, hardisk bekas, stopwatch, dan beban 250 gram. Adapun bahan yang diperlukan dalam penelitian ini adalah lem, meteran, zat cair, dan benang.

Penelitian dilakukan melalui tiga tahap yaitu perancangan, perakitan dan pengujian alat. Proses perancangan alat bertujuan untuk membuat sketsa umum alat viskometer stirer. Desain rancangan viskometer stirer ditunjukkan oleh Gambar 1.

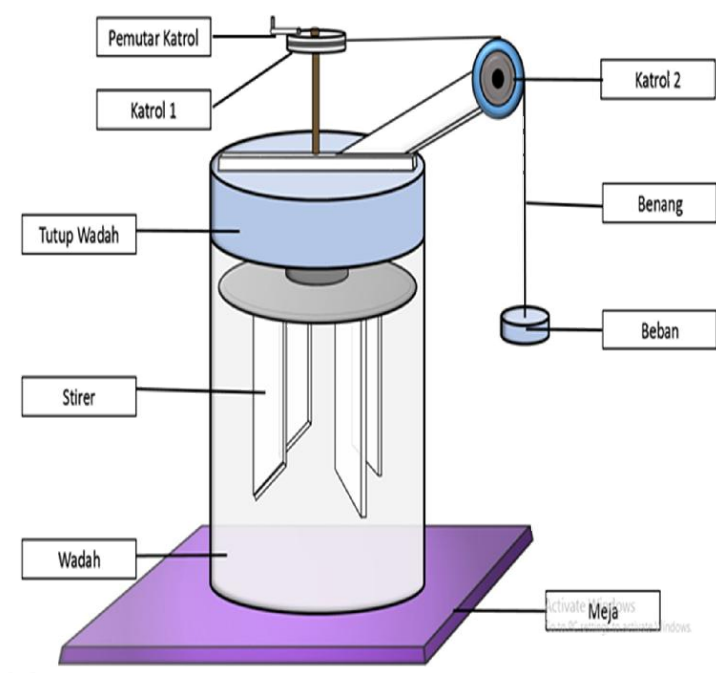

Gambar 1. Desain rancangan alat.
Bagian-bagian alat viskometer stirer ini terdiri dari:

a. Katrol yang digunakan sebanyak dua buah, katrol 1 dibawah pemutar dan katrol 2 terletak di atas beban seperti gambar. Katrol berputar tanpa hambatan, sehingga gesekan pada katrol mendekati nol.

b. Pemutar katrol, berfungsi untuk memutar katrol yang dihubungkan ke stirer, sehingga ketika pemutar katrol dan katrol 1 berputar, stirer juga ikut berputar.

c. Benang, berfungsi untuk menghubungakan beban dengan penutar katrol.

d. Beban, berfungsi sebagai pemberat sehingga ketika beban ini dijatuhkan, katrol berputar.

e. Tutup wadah, berfungsi agar ketika stirer berputar air dalam wadah tidak tumpah.

f. Stirer, berfungsi untuk memutar air dalam wadah. Panjang stirer harus mengenai $3 / 4$ dari tinggi zat cair.

g. Wadah, tempat menyimpan air yang akan diputar oleh stirer. Tabung/wadah zat cair terbuat dari kaca, supaya dinding wadah tidak mengalami perubahan.

h. Meja, berfungsi sebagai dudukan wadah.

Tahapan perakitan viskometer stirer adalah sebagai berikut: a) akrilik dipotong berbentuk lingkaran dengan jari-jari $2 \mathrm{~cm}$ buah, b) akrilik dibentuk menjadi sebuah katrol, c) akrilik dipotong berbentuk persegi panjang dengan ukuran $2 \times 4 \mathrm{~cm}$ sebanyak 4 buah, d) akrilik dibentuk menjadi runcing bagian bawah menyerupai pedang, e) dilubangi penutup wadah sebesar $1 \mathrm{~cm}$ untuk tempat masuknya stirer, f) dibongkar hardisk, dan diambil beberapa komponen seperti cd, pemutar, dan komponen lainnya, g) merakit komponen yang telah diambil dari hardisk menjadi sebuah katrol, h) menempelkan katrol kedalam baut panjang dengan ujung $\mathrm{cd}$, i) menempelkan akrilik berbentuk pedang ke cd untuk menyerupai stirer dan masukkan ke dalam wadah, j) menempelkan katrol yang terbuat dari akrilik diujung wadah sejajar dengan tinggi katrol pertama, k) menempelkan meteran ke meja wadah yang memiliki ketinggian 1 meter, 1) menyambungkan benang dan beban ke katrol dengan panjang 1 meter, $\mathrm{m})$ viskometer stirer selesai dirakit.

Langkah-langkah eksperimen dalam menggunakan alat praktikum viskositas ini adalah sebagai berikut: Alat dalam keadaan 
berisi air, tali diputar pada bagian katrol, sehingga beban berada pada posisi atas. Setelah itu diletakkan beban pada ujung tali dan tahan. Selanjutnya, beban dilepaskan dan diamati pergerakan benda. Saat benda bergerak tanpa percepatan (kecepatan konstan) baru dimulai penghitungan jarak tempuh beban, hasilnya ditulis dalam lembar pengamatan. Pada saat yang sama diukur waktu yang diperlukan beban selama gerak yang diperhitungkan tersebut, hasilnya dicatat dalam lembar pengamatan. Data yang diperoleh selanjutnya diolah dengan menggunakan persamaan (1) berikut:

$$
\eta=\left(\frac{r_{l}-r_{d}}{h}+\frac{l}{r_{d}}\right)\left(\frac{r_{k} m g t}{2 \pi r_{d}^{2} x}\right)(\text { Pa.s })
$$

dengan:

$$
\begin{aligned}
& \mathrm{m}=\text { massa benda } \\
& g=\text { percepatan gravitasi bumi } \\
& r_{d}=\text { jari-jari silinder pejal } \\
& r_{l}=\text { jari-jari silinder luar } \\
& h=\text { tinggi silinder pejal } \\
& r_{k}=\text { jari-jari katrol } \\
& \begin{aligned}
l= & \text { jarak antara permukaan dengan tutup } \\
& \text { silinder } \\
t= & \text { wakti yang dibutuhkan beban un tuk } \\
& \text { turun } \\
x= & \text { panjang lintasan. }
\end{aligned}
\end{aligned}
$$

Pengujian diulang untuk zat cair lain yang akan ditentukan koefisien viskositasnya. Zat cair dimasukkan ke dalam silinder. Mengulangi percobaan untuk memperoleh hasil yang akurat.

Validitas viskometer stirer yang dirancang dilihat dengan menguji lama waktu mengalir suatu zat cair dalam viskometer, lalu membandingkannya dengan nilai viskositas standar. Demonstrasi ini dilakukan di depan para ahli untuk mendapatkan penilaian dan masukan.

\section{Hasil dan Pembahasan}

Hasil penelitian ini berupa rancang bangun sebuah alat penguji viskositas stirer dan data percobaan praktikum menggunakan alat yang sudah dirancang. Rancangan bentuk viskometer stirer yang sudah dibuat ditampilkan melalui Gambar 2. Bagian-bagian dari viskometer stirer yaitu:

1. Pemutar Katrol

2. Katrol 1

3. Penutup wadah

4. Stirer berfungsi sebagai pengaduk zat cair

5. Meja berfungsi sebagai tempat wadah

6. Skala berfungsi sebagai acuan pengukuran jarak

7. Katrol 2 berfungsi sebagai penggerak katrol 1

8. Benang berfungsi sebagai penghubung beban, katrol 1, dan katrol 2

9. Wadah berfungsi sebagai tempat zat cair yang mau diukur

10. Beban berfungsi sebagai penggerak katrol 1

11. Stopwacth berfungsi sebagai pengukur waktu.

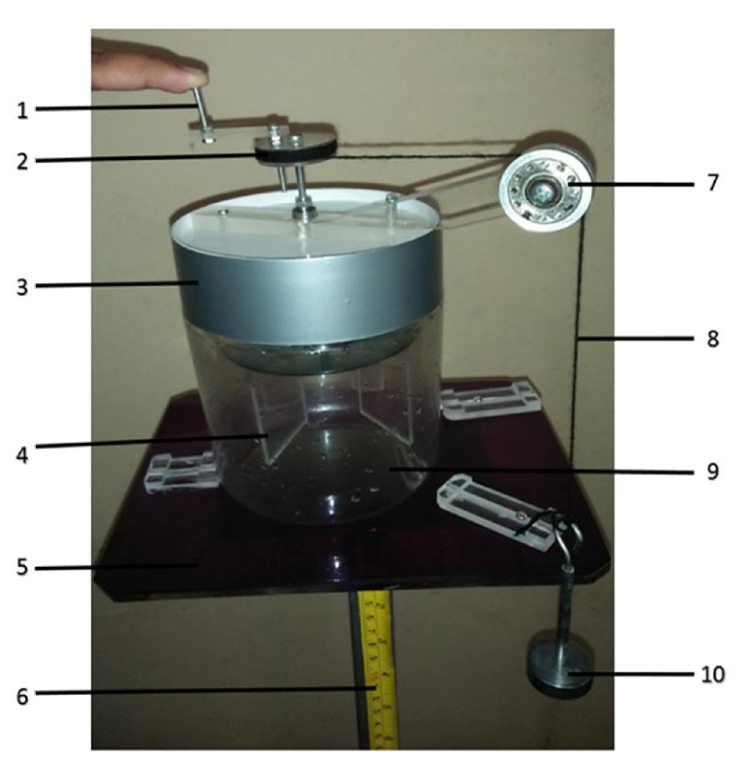

Gambar 2. Alat viskometer stirer.

Pengujian viskositas dilakukan dalam empat tahapan, yakni pengukuran pertama dan kedua dilakukan dengan menggunakan air biasa dengan suhu $29^{\circ}$ dan $50^{\circ}$ dan pengukuran ketiga dan keempat dilakukan dengan menggunakan minyak goreng dengan suhu $29^{\circ}$ dan $50^{\circ}$, masing-masing tahapan dilakukan tiga kali pengukuran. Besarnya viskositas zat cair yang diukur dilakukan melalui perhitungan waktu yang didapatkan selama beban turun sejauh 1 meter. Data hasil percobaan ditunjukkan oleh Tabel 1. 
Hasil pengujian alat pengukur viskositas yang didapatkan melalui praktikum selanjutnya dibandingkan dengan perhitungan secara teoretis. Nilai viskositas zat cair secara teoretis bisa dihitung menggunakan persamaan (1).

Tabel 1. Data hasil pengujian zat cair

\begin{tabular}{|c|c|c|c|c|}
\hline $\begin{array}{l}\text { Zat } \\
\text { Cair }\end{array}$ & Suhu & $\begin{array}{c}\text { Pengu- } \\
\text { kuran }\end{array}$ & Waktu & $\begin{array}{c}\text { Waktu } \\
\text { Rata- } \\
\text { Rata }\end{array}$ \\
\hline \multirow{6}{*}{$\begin{array}{l}\text { Air } \\
\text { Biasa }\end{array}$} & \multirow{3}{*}{$30^{\circ} \mathrm{C}$} & I & $4,20 \mathrm{~s}$ & \multirow{3}{*}{$4,26 \mathrm{~s}$} \\
\hline & & II & $4,30 \mathrm{~s}$ & \\
\hline & & III & $4,30 \mathrm{~s}$ & \\
\hline & \multirow{3}{*}{$50^{\circ} \mathrm{C}$} & I & $4,10 \mathrm{~s}$ & \multirow{3}{*}{$4,13 \mathrm{~s}$} \\
\hline & & II & $4,10 \mathrm{~s}$ & \\
\hline & & III & $4,20 \mathrm{~s}$ & \\
\hline \multirow{6}{*}{$\begin{array}{l}\text { Minyak } \\
\text { Goreng }\end{array}$} & \multirow{3}{*}{$30^{\circ} \mathrm{C}$} & I & $04,90 \mathrm{~s}$ & \multirow{3}{*}{$04,83 \mathrm{~s}$} \\
\hline & & II & $04,80 \mathrm{~s}$ & \\
\hline & & III & $04,80 \mathrm{~s}$ & \\
\hline & \multirow{3}{*}{$50^{\circ} \mathrm{C}$} & I & $04,03 \mathrm{~s}$ & \multirow{3}{*}{$04,08 \mathrm{~s}$} \\
\hline & & II & $04,11 \mathrm{~s}$ & \\
\hline & & III & $04,11 \mathrm{~s}$ & \\
\hline \multirow{6}{*}{ Pertalite } & & $\mathrm{I}$ & $03,80 \mathrm{~s}$ & \multirow{3}{*}{$03,76 \mathrm{~s}$} \\
\hline & $30^{\circ} \mathrm{C}$ & II & $03,70 \mathrm{~s}$ & \\
\hline & & III & $03,80 \mathrm{~s}$ & \\
\hline & \multirow{3}{*}{$50^{\circ} \mathrm{C}$} & I & $03,20 \mathrm{~s}$ & \multirow{3}{*}{$03,16 \mathrm{~s}$} \\
\hline & & II & $03,20 \mathrm{~s}$ & \\
\hline & & III & $03,10 \mathrm{~s}$ & \\
\hline
\end{tabular}

Pengukuran viskositas yang tepat dengan cara di atas sulit dicapai. Hal ini disebabkan harga $r_{d}, r_{k}$ dan $r_{l}$ sukar ditentukan secara tepat. Kesalahan pengukuran terutama rd, sangat besar pengaruhnya karena harga ini dipangkatkan tiga. Untuk menghindari kesalahan tersebut dalam prakteknya digunakan suatu cairan pembanding. Cairan yang paling sering digunakan adalah air. Pada pengukuran viskositas menggunakan alat ini juga tidak dapat diketahui kesalahan relatifnya, karena tidak adanya besar viskositas zat cair secara teoritis. Sehingga pada alat viskometer stirer ini hanya dapat menunjukkan pengaruh selang waktu yang dibutuhkan oleh beban untuk jatuh ketanah akibat hambatan yang diberikan fluida kepada stirer dan suhu zat cair dengan nilai viskositas zat cair.

Untuk dua cairan yang berbeda dengan pengukuran alat yang sama, berlaku hubungan $\frac{\eta_{1}}{\eta_{2}}=\frac{t_{1}}{t_{2}}$. Jadi, bila $\eta$ cairan pembanding diketahui, maka dengan mengukur waktu yang diperlukan untuk mengalir kedua cairan melalui alat yang sama dapat ditentukan $\eta$ cairan yang belum diketahui. Hal ini dapat digunakan karena diseluruh pengukuran variabel bebasnya hanya pada waktu (t). Hal ini sesuai dengan kesimpulan hasil penelitian yang diperoleh Ridwan et al., (2012) bahwa semakin kecil waktunya yang diperoleh, maka semakin besar viskositas fluidanya. Penelitian tentang viskositas dengan uji coba terhadap fluida madu juga dilakukan oleh Apriani et al., (2013) yang mana dalam kajian tersebut menggunakan lama waktu alir fluida sebagai salah satu faktor yang menentukan nilai viskositas madu. Hasil yang diperoleh adalah, fluida (madu) dengan waktu alir lebih lama memiliki nilai viskositas lebih tinggi.

Berdasarkan data pengukuran pada Tabel 1 dapat dilihat bahwa viskositas minyak goreng lebih tinggi dibandingkan viskositas air, dan viskositas pertalite lebih rendah dibandingkan viskositas air. Hal ini berarti, diantara ketiga jenis fluida yang dibandingkan, pertalite memiliki kekentalan yang paling rendah. Pengujian terhadap suhu menunjukkan hasil bahwa semakin tinggi suhu fluida, maka viskositasnya semakin rendah.

\section{A. Pengukuran pada suhu $30^{\circ} \mathrm{C}$ \\ $\eta_{\text {air }}=7,96 \times 10^{-4} \mathrm{~N} . \mathrm{s} / \mathrm{m}^{2}$ \\ $\mathrm{t}_{\mathrm{air}}=04,26$ sekon}

Tabel 2. Data pengujian viskositas zat cair suhu $30^{\circ} \mathrm{C}$

\begin{tabular}{ccccc}
\hline No & $\begin{array}{c}\text { Jenis } \\
\text { zat cair }\end{array}$ & $\begin{array}{c}\text { Wak- } \\
\text { tu } \\
(\mathbf{s})\end{array}$ & $\begin{array}{c}\text { Viskositas } \\
\left(\mathbf{N . s} / \mathbf{m}^{2}\right)\end{array}$ & $\begin{array}{c}\text { Viskositas } \\
\text { rata-rata } \\
\left(\mathbf{N . s} / \mathbf{m}^{2}\right)\end{array}$ \\
\hline \multirow{3}{*}{1} & Minyak & 04,90 & $9,15 \times 10^{-4}$ & \\
& goreng & 04,80 & $8,96 \times 10^{-4}$ & $9,02 \times 10^{-4}$ \\
& & 04,80 & $8,96 \times 10^{-4}$ & \\
\hline \multirow{3}{*}{2} & Pertalite & 03,80 & $7,10 \times 10^{-4}$ & \\
\cline { 3 - 4 } & & 03,70 & $6,91 \times 10^{-4}$ & $7,03 \times 10^{-4}$ \\
& & 03,80 & $7,10 \times 10^{-4}$ & \\
& & & &
\end{tabular}




\section{B. Pengukuran pada suhu $50^{\circ} \mathrm{C}$}

$\eta_{\text {air }}=5,47 \times 10^{-4} \mathrm{~N} . \mathrm{s} / \mathrm{m}^{2}$

$\mathrm{t}_{\mathrm{air}}=04,13$ sekon

Tabel 3. Data pengujian viskositas zat cair suhu $50^{\circ} \mathrm{C}$

\begin{tabular}{ccccc}
\hline No & $\begin{array}{l}\text { Jenis } \\
\text { zat cair }\end{array}$ & $\begin{array}{l}\text { Waktu } \\
\text { (s) }\end{array}$ & $\begin{array}{l}\text { Viskositas } \\
\left(\mathbf{N . s} / \mathbf{m}^{2}\right)\end{array}$ & $\begin{array}{l}\text { Viskositas } \\
\text { rata-rata } \\
\left(\mathbf{N . s} / \mathbf{m}^{2}\right)\end{array}$ \\
\hline \multirow{4}{*}{1} & Minyak & 04,03 & $5,33 \times 10^{-4}$ & \\
& goreng & 04,11 & $5,44 \times 10^{-4}$ & $5,40 \times 10^{-4}$ \\
& & 04,11 & $5,44 \times 10^{-4}$ & \\
\hline \multirow{2}{*}{2} & \multirow{3}{*}{ Pertalite } & 03,20 & $4,23 \times 10^{-4}$ & $4,18 \times 10^{-4}$ \\
& & 03,20 & $4,23 \times 10^{-4}$ & \\
& & 03,10 & $4,10 \times 10^{-4}$ & \\
\hline
\end{tabular}

Setelah alat viskometer stirer selesai dibuat dengan rancangan yang ada, maka dilakukan percobaan dan pengujian alat untuk mengetahui alat viskometer stirer dapat digunakan untuk mengukur viskositas zat cair atau tidak. Setelah dilakukan percobaan, alat viskometer stirer ini dapat digunakan untuk mengukur viskositas zat cair, dapat dilihat dari data yang diperoleh pada pengujian alat tersebut, dimana data yang didapatkan bisa diketahui viskositas zat cair yang diukur.

Adapun setelah dilakukan percobaan dan pengujian alat viskometer stirer ini, diperoleh hasil bahwa terdapat hubungan antara selang waktu yang dibutuhkan oleh beban untuk jatuh ketanah akibat hambatan yang diberikan fluida kepada stirer dan suhu zat cair dengan nilai viskositas zat cair. Hubungannya selang waktu yang dibutuhkan oleh beban untuk jatuh ketanah akibat hambatan yang diberikan fluida kepada stirer dengan nilai viskositas zat cair yakni berbanding lurus. Semakin lama selang waktu yang dibutuhkan oleh beban untuk jatuh ke tanah akibat hambatan yang diberikan fluida kepada stirer, maka semakin tinggi nilai viskositas suatu zat cair dan sebaliknya semakin cepat selang waktu yang dibutuhkan oleh beban untuk jatuh ke tanah akibat hambatan yang diberikan fluida kepada stirer, maka semakin rendah nilai viskositas zat cair.

Tabel 2 dan Tabel 3 menunjukkan bahwa semua fluida yang diamati mengalami penurunan kekentalan ketika dipanaskan pada suhu $30^{\circ} \mathrm{C}$ dan $50^{\circ} \mathrm{C}$. Minyak goreng pada suhu $30^{\circ} \mathrm{C}$, memiliki nilai viskositas $9,02 \times 10^{-4}$ dan pada suhu $50^{\circ} \mathrm{C}$ memiliki nilai viskositas $5,40 \times$ $10^{-4}$. Pada pertalite, nilai viskositas pada suhu $30^{\circ} \mathrm{C}$ adalah $7,03 \times 10^{-4}$ dan pada suhu $50^{\circ} \mathrm{C}$ memiliki nilai viskositas $4,18 \times 10^{-4}$.

Hubungan suhu zat cair dengan viskositas zat cair adalah berbanding terbalik. Dimana semakin tinggi suhu zat cair, maka semakin rendah nilai viskositas zat cair, dan sebaliknya semakin semakin rendah suhu zat cair, maka semakin tinggi nilai viskositas zat cair tersebut. Hal ini terlihat dari semakin tinggi suhu benda waktu alirnya semakin cepat. Hal ini sesuai dengan penelitian yang diperoleh oleh Maulida (2010) dengan objek penelitiannya adalah oli dimana diperoleh bahwa fluida bersifat lebih encer ketika dipanaskan. Pada saat dipanaskan, gaya kohesi antar partikel fluida menjadi berkurang sehingga nilai viskositasnya menjadi berkurang (Olson, 1993).

Pengujian validitas viskometer stirer dilakukan dengan cara mendemonstrasikan percobaan pengujian viskositas di depan tiga orang tenaga ahli. Selanjutnya, hasil percobaan dibandingkan dengan nilai standar. Setelah kegiatan demonstrasi menggunakan alat ini, maka para ahli memberi penilaian dan masukan. Berdasarkan keputusan tenaga ahli tersebut, dinyatakan bahwa viskometer stirer valid dalam mengukur viskometer suatu zat cair.

\section{Kesimpulan dan Saran}

Alat viskometer stirer yang dirancang ini dapat untuk digunakan dalam melakukan pengukuran viskositas zat cair dengan indikator waktu dan suhu. Hasil pengujian membuktikan bahwa semakin lama selang waktu yang dibutuhkan oleh beban untuk jatuh ke tanah akibat hambatan yang diberikan fluida kepada stirer, maka semakin tinggi nilai viskositas suatu zat cair dan sebaliknya jika semakin cepat selang waktu yang dibutuhkan oleh beban untuk jatuh ke tanah akibat hambatan yang diberikan fluida kepada stirer, maka semakin rendah nilai viskositas zat cair. Hubungan suhu zat cair dengan viskositas zat cair adalah berbanding terbalik. Sehingga semakin tinggi suhu zat cair, maka semakin rendah nilai viskositas zat cair, dan sebaliknya semakin semakin rendah suhu 
zat cair, maka semakin tinggi nilai viskositas zat cair tersebut.

Berdasarkan hasil kajian ini, disarankan agar penelitian selanjutnya pada alat viskometer stirer dapat dilakukan uji validitas oleh pakar dan pengguna. Alat ini hendaknya digunakan juga untuk mengamati indikator lain selain waktu dan suhu. Viskometer yang dirancang dapat menggunakan metode lain seperti metode bola jatuh dan tabung. Selain ini, pengujian terhadap viskometer stirer dapat dilakukan hingga tahap pengujian kepraktisan penggunaan alat.

\section{Daftar Pustaka}

Apriani, D, Gusnedi, \& Yenni Darvina, 2013. Studi Tentang Nilai Viskositas Madu Hutan dari Beberapa Daerah di Sumatera Barat untuk Mengetahui Kualitas Madu. Pillar of Physics, 2 (1), 91-98.

Maulida, H., \& Rani, E., 2012. Analisis Karakteristik Pengaruh Suhu dan
Kontaminan Terhadap Viskositas Oli Menggunakan Rotary Viscometer. Jurnal Neutrino, 3 (1), 18-31.

Olson, R. 1993. Dasar-dasar Mekanika Fluida Teknik; Edisi kelima. PT Gramedia Pustaka Utama, Jakarta.

Ridwan, R., Wiseno, E., \& Suwargo, P. G., 2012. Pembuatan dan Pengujian Viskometer Tabung. Skripsi Program Studi Teknik Informatika.

Samdara, R., Bahri, S., \& Muqorobin, A., 2008. Rancang Bangun Viskometer Dengan Metode Rotasi Berbasis Komputer: GRADIEN, 4 (2), 342-348.

Shanti, M. R. S., Oktaviara, A., Sutresno, A., \& Wibowo, N. A., 2014. Pembuatan media pembelajaran pengukuran viskositas dengan menggunakan viskometer dua kumparan dan freewave 3. Jurnal Pendidikan Fisika Indonesia, 10 (1), 28-35.

Sugiyono, 2012. Metode Penelitian Kuantitatif, Kualitatif dan $R \& D$. Alfabeta, Bandung. 